\title{
Quality of Educational Resources: A Comparative Evaluation of Schools That Joined PISA 2015 from Turkey and Singapore
}

\author{
Metin Özkan ${ }^{1}$, Suphi Balcı ${ }^{2}$ Selman Kayan ${ }^{2} \&$ Engin Iş $^{3}$ \\ ${ }^{1}$ Faculty of Education, Gaziantep University, Gaziantep, Turkey \\ ${ }^{2}$ Ministry of National Education, Turkey \\ ${ }^{3}$ Faculty of Sciense and Art, Mardin Artuklu University, Mardin, Turkey \\ Correspondence: Metin Özkan, Faculty of Education, Gaziantep University, Gaziantep, Turkey. Tel: \\ 90-342-317-3773. E-mail: ozkan.metin@gmail.com
}

Received: November 24, 2017

doi:10.5539/ies.v11n4p132
Accepted: December 28, 2017 Online Published: March 28, 2018

URL: https://doi.org/10.5539/ies.v11n4p132

\begin{abstract}
The objective of the study was to make a comparison among the two countries according to the level of sufficiency of educational resources and to determine the accuracy level at which variables related to educational resources can classify the schools on the basis of countries. Relational survey model was used. The sample group of the study was comprised of 186 schools from Turkey and 174 schools from Singapore for a total of 360 schools. Descriptive analyses and chi-square statistics were used to put forth whether there are differences with regard to the items. Logistic regression analysis was used to make an accurate classification of the schools according to their countries. Statistically significant differences between Turkish and Singapore schools were attained as a result of the chi-square analyses in all variables including lack of educational material, inadequate or poor quality educational material, lack of physical infrastructure and inadequate or poor quality physical infrastructure variables. A total of four variables included in the study explain about $60 \%$ of the variance of Turkish and Singapore schools in having adequate educational resources. The equation obtained from analysis shows that lack of educational material is more important than lack of physical infrastructure. This alone puts forth that school success is related more to the quality of educational material than to physical inadequacies. As a result of the logistic regression with these variables, it was determined that the equation classifies $82 \%$ of the total number of 360 schools accurately. As a general conclusion of the study, it was observed with regard to its contributions to the model acquired via logistic regression.
\end{abstract}

Keywords: lack of educational materials, physical infrastructure, quality of teaching material, quality of the physical infrastructure

\section{Introduction}

Education which makes up the foundation of the human capital of countries is a significant process that enables the development of both the individuals and society, supports economic development while developing and protecting cultural values to pass them down to future generations. Education, with impacts such as strengthening the development and welfare of individuals and society, is an important indicator of the development levels of countries. The advancement of countries is directly proportional to the importance they give to education (Güngör \& Göksu, 2013). Ensuring that the changes in the behaviors of self-realized individuals with high self-confidence in the changing and developing world can be sustained in addition to raising individuals who can adopt to these changes, respond to the expectations of the twenty-first century, question and research is possible only by education (Anil, 2009).

Education environment can make a positive impact on the educational experiences of both students as well as all members of the school. Education environments required by an efficient education system with its different dimensions can be evaluated as a mediator to increase the learning of students in addition to ensuring that the students are happy and that their communication skills are developed. Physical conditions in schools along with factors that are not related to courses such as security, guidance and nutrition have direct impacts on students. Therefore, education environments should be planned by taking into consideration their different dimensions and the happiness of students should also be taken into consideration as a priority when developing education policies 
in addition to considering the physical needs and requirements when making such plans (ERG, 2016).

The quality of the physical conditions of schools is of great importance to ensure that students have positive school experience and that they are happy. Physical conditions that are of significant importance for students, as well as the educators, should be evaluated on a wide scale ranging from the heating of the school to the cleanliness of toilets; from whether the school has a suitable garden, library, laboratory and a gymnasium to whether the size, quality and number of classrooms meet the demands put forth by standards or not. Students who spend a majority of their lives in the school environment need safe and well-equipped learning environments as much as they need academic support. The facilities students have access at schools have a significant impact on their happiness. The reason for this is that the environment of the child is among the leading factors that affect his/her happiness. In addition to their impact on the welfare of children, the support provided by the facilities in these environments is critical. It is due to this importance that the families of children who will start school give priority to the quality of learning environments (Walford, 2003).

Proper learning environments are crucial for the transfer and use of new technologies and materials in the field of education as well as to improve the quality of education. Learning environments in education, use of new technologies and materials enable students to learn more easily and faster while also providing job satisfaction to the students (Davis, 2003).The use of materials in education plays an important role in the program's success by supporting the students to reach the projected goals more easily via more effective education environments (Çelik, 2007). Improper education environments, inability to make use of educational materials or inability to put forth required facilities to make use of these materials are considered as plain failures for that education system. Hence, education should be based on the most advanced education technology, suitability of the physical environment as well as proper materials. The goal in the rapidly changing world of the $21^{\text {st }}$-century is to raise individuals who know different means of reaching knowledge, who can use these means and who can cope with problems they face by using knowledge as an effective tool instead of individuals who obtain knowledge from a single source and memorize. Individuals gain these skills if teachers prepare effective and interactive learning environments (Şahin \& Yıldırım, 1999)

How the education environments should be organized to meet the learning needs of the individuals of today's $21^{\text {st }}$-century information society is an important problem. Countries have to give an effective response to this problem to come to the forefront in the civilization race. International wide scale tests are used as an important mediator for this purpose. Program for International Student Assessment (PISA) is a wide scale study with an objective of making a multifaceted evaluation and comparison of the education systems of countries by the Organization for Economic Cooperation and Development (OECD).The evaluation carried out in the project focuses on the skills of students in using their accumulated knowledge to solve problems they might face in real life rather than assessing the academic knowledge of students with regard to a particular school curriculum and as such, it is considered as a prospective evaluation method. PISA has been applied predominantly in OECD countries as well as countries and/or economies that wish to take part since the year 2000.This research, which is conducted as a three-year period, focuses on a different area every three years. The process that started in the year 2000 by focusing on reading skills continued respectively with mathematics, science, reading skills, mathematics and finally in 2015 with science literacy.

Singapore attracts attention with its excellent success in recent years in international student assessment examinations such as PISA, TIMMS (Trends in International Mathematics and Science Study) and PIRLS (Progress in International Reading Literacy Study), etc. The success of Singapore in international examinations that provides information on the results of the policies and applications of world governments in the field of education has attracted significant attention all over the world. It is essential to put forth the differences in the Singapore education system that provide an added value especially for countries such as Turkey which strive to improve their education systems but cannot attain the desired successes in international evaluation studies.

The Singapore education system that became very successful in student assessment examinations such as PISA, TIMMS and PIRLS has been evaluated by international achievement evaluation institutions and as a result, it has been put forth that it is entirely different from those of other countries in many aspects. "Education Systems with the Highest Performance" from among those of the countries in the world were evaluated by an institution named McKinsey and Singapore ranked above many countries that were included in the study. According to the report published by this institution, the Singapore education system was observed as having an average performance in 1985 , however the positive impact of the reforms that went into effect after this date was started to be observed and it was stated that the education system became perfect after the year 2000 (Bakioğlu \& Göçmen, 2013).

Singapore has been in the top rankings in all PISA examinations it participated in despite the fact that it is not an 
OECD member. The first place ranking of Singapore in PISA 2015 was an indication that its success has not been coincidental. However, Singapore's success is not limited to only a single examination or a single application. Singapore was ranked first with a score of 597 among the eight grades for science and technology in TIMMS 2015; it was ranked first in mathematics with a score of 621 ; it was ranked first among fourth grades in mathematics with a score of 618 and first in science and technology with a score of 590 (Mullis, Martin, Foy, \& Arora, 2012; MEB [Ministry of National Education Republic of Turkey], 2016). Singapore was ranked second in the first PISA it participated in during the year 2009 in mathematics literacy with a score of 562; fifth in reading skills with a score of 526; fourth in science literacy with a score of 542; second in mathematics literacy in 2012 with a score of 573; third in reading skills with a score of 542; third in science literacy with a score of 551; first in mathematics literacy in 2015 with a score of 564; first in reading skills with a score of 535; first in science literacy with a score of 556 (Cemaloğlu, 2016).

Successes of countries in education are affected by many different variables. One of these variables is directly related tothe budget that the countries allocate for education. When the budget of Singapore is examined, it is observed that about $20 \%$ is allocated for education expenses. The education expenses of Singapore has increased periodically starting from 2010 and an increase of about $50 \%$ was made in the year 2015 for secondary education which is higher than the share allocated to primary education. Whereas the expense per student in primary education was 6 thousand dollars in 2010, this value increased to about 10 thousand dollars in 2015. Similarly, whereas 9 thousand dollars was being spent per student in secondary education in 2010, this amount increased up to 13,5thousand dollars in 2015 (Singapore in Figures, 2016). The total budget of the country allocated to education was 6 billion dollars in 2001 which reached about 12 billion dollars in 2015 (Education at a GlanceSingapore, 2016). Per capita income from among the 293 billion dollars gross national product of Singapore is about 53 thousand dollars. Whereas this amount in Turkey has been actualized as nearly 9 thousand dollars from among the 719 billion dollars gross national product (World Bank, 2016). The ratio of education expenses to GNP is observed as $2.8 \%$ as of 2013 (Education at a GlanceSingapore, 2016). Comparative data indicate that the share of the government in the education expenses of Turkey is lower in comparison with the OECD average. The share of the government in education expenses is $91 \%$ in OECD and $87 \%$ in Turkey (OECD, 2016). The number of R\&D specialists was 6658 in Singapore and 1157 in Turkey (World Bank, 2016). The number of R\&D specialists in Singapore is about six times greater than that of Turkey.

The primary objectives of the Singapore education system are to help students discover their own skills; realize their own potential while also raising a lifelong desire and passion to learn in them. The strong aspects of the Singapore education system are that it has a wide base and a holistic emphasis on learning, that its schools provide rich learning opportunities to students not only in terms of physical, aesthetic, moral and social-emotional aspects but also in terms of cognitive aspects as well, the rich education content provided to students, orientations towards their fields of talent and enriched education programs resulting in more qualified students with strong fundamental values which are important in our ever changing contemporary world such as creativity, trust, compassion (Education in Singapore, n.d.). As a result, it can be stated that the success that Singapore attained according to PISA and TIMMS results is not coincidental but an outcome of the program methods and techniques applied, class tools, measurement and evaluation system as well as the policies related to the physical infrastructure of education.

Turkey has participated in all three-year cycles of PISA since it participated for the first time in 2003. Turkey was ranked among the lowest countries of OECD in these cycles in the field of science literacy and was ranked below average among all participating countries. According to PISA 2015 results, Turkey dropped by about 7 spots on average according to the PISA 2012 results in the fields of mathematics, science and reading among the 540 thousand students at the 15 -year-old level from 72 countries. The most considerable loss was in reading and science with a loss of 9 spots. Whereas Turkey was ranked number 43 in PISA 2012 with a score of 463 in the field of science, it was ranked $52^{\text {nd }}$ with 425 in 2015 . Turkey was ranked $50^{\text {th }}$ among 72 countries. Physical infrastructure in education and insufficient materials can be provided as reasons for this. As is the case for almost all levels of education, it can be indicated that lack of financing in addition to physical infrastructure insufficiencies such as shortcomings in buildings and facilities along with significant laboratory equipment, computer and library insufficiencies are significant issues (Gedikoğlu, 2005).

It is known that the schools in Turkey have had physical infrastructure problems for many years. Physical infrastructure and equipment issues may prevent education activities to take place at the beginning of every year. The number of schools that carry out double-shift schooling as morning/afternoon has increased with the change to the "4+4+4" system in 2012. The ratio of double shift schools during the 2011-12 academic year which was the last prior to the application of the " $4+4+4$ " system was about $22 \%$ at the primary school level. This ratio increased to $29.2 \%$ in 2012 and decreased down to $26 \%$ in 2013 and $23.5 \%$ in 2014. Despite this decrease, recent data obtained 
from the Ministry of Development regarding the issue indicate that $54 \%$ of the primary school students during the 2014-15 academic year and 47\% of the secondary school students have attended double-shift schools. As of 2014, the ratio of schools with a gym was only $8.4 \%$. The ratio of schools with multi-purpose hall/conference hall was $36 \%$, and the ratio of schools with a library was $39.2 \%$ (MEB, 2015).

Sarış1k and Düşkün (2016) carried out a study in which they put forth that the ratio of students who indicate that their schools are not heated sufficiently was $41 \%$ at double shift schools and $34 \%$ at full day schools. Having a gym in the school environment where students can carry out physical activities is of great importance for both physical and mental development as well as for the health of students. According to data put forth by the researchers, the ratio of schools with gyms is quite low. Of the $4^{\text {th }}$ grade students, $34 \%$ indicate that they have a gym they can use at their schools, whereas this ratio was $40 \%$ for $5^{\text {th }}$ grade students and $29 \%$ for $7^{\text {th }}$ grade students. The existence of libraries and their use has also been identified as problematic. Of the children who participated in the study, 54\% indicated that their schools have a library at their schools which they can use comfortably. This ratio was $55.5 \%$ for $4^{\text {th }}$ grade students and $54 \%$ for $5^{\text {th }}$ grade students and $51 \%$ for $7^{\text {th }}$ grade students. According to the findings of this study, students complain about cold classrooms, toilets with cleanliness issues and lack of facilities. It is also indicated that facilities in schools such as libraries, gyms, computer rooms and laboratories may be lacking in addition to being used outside classroom hours for different purposes and thus closed to students' access (ERG, 2016).

The numbers of actors and components in the education system of countries such as classrooms, schools, students and teachers as well as the environment that students face at schools are of crucial importance for the happiness and success of students. For this purpose, numerical data regarding the components that make up the education environments are among the most critical indicators of the success of education policies. The quality of education is not equal in all societies. Those that are lacking behind the age that we live in have attributed this to the fact that their education systems are not good enough. These countries have strived to make changes in their education policies and systems while also benefiting from the educational experiences of other countries thus trying to establish education systems which resemble those of successful countries' (Ergün, 1985).

In addition to the PISA results; international and European Union education norms, technologic and economic developments that take place at the global scale, the demand for quality education as well as the desire to reach an education system that will provide economic development, inadequacy of the current educational system in meeting the needs require the necessity to make some changes in education in Turkey (Akpınar \& Aydın, 2007). In the light of all these requirements and needs, training programs enriched with student-centered education, multiple intelligence, spiral, thematic and skill approaches and consideration of individual differences have been designed and implemented by constructivist teaching approach which became rapidly-spreading after the Ministry of Education carried out pilot applications in 2004in nine provinces within the framework of the planned education program reform (ERG, 2005). FATIH (Movement to Increase Opportunities and Technology) project which was applied in 2010 and is still ongoing is another application that was developed to increase quality in education and to provide equal opportunities. Obligatory education in Turkey was increased from 8 to 12 years in 2012 when the 12 Year Obligatory Education System $(4+4+4$ education system) went into effect together with the law numbered 6287 during the 2012-2013 academic year. The Ministry of Education declared that the academic program would be changed for the 2017-2018 academic year. Despite all these developments, it is certain that Turkey needs the development of effective education policies and more comprehensive education reforms in order to climb higher in world rankings. It is apparent that Turkey is in search of new developments in education and it is considered of great importance to examine the course materials that stand out in countries such as Singapore which has received significant successes in PISA and other similar international evaluation studies in addition to examining how these countries overcome issues such as physical infrastructure.

\subsection{Objective}

One of the general objectives of PISA is that it enables comparisons among countries while also provides data based clues regarding the development of countries. It is considered as necessary to compare Turkey which is clearly searching for new grounds in education and Singapore which stands out with its continuous success in PISA in terms of science literacy as well as the quality of educational resources. Based on this requirement, the objective of the study was to make a comparison among the two countries according to the level of sufficiency of educational resources (lack of educational materials, inadequate or poor quality educational material, lack of physical infrastructure and inadequate or poor quality physical infrastructure) and to determine the accuracy level at which variables related to educational resources can classify the schools on the basis of countries. 


\section{Method}

\subsection{Study Model}

In this study, relational survey model was used. According to Karasar (2008), the relational survey model is a research model aimed at determining the existence of interchanges and/or the degree between two or more variables.

\subsection{Target Population and Study Group}

A total of 72 countries participated in PISA 2015 application. PISA is a study that includes 15 year old students. This student group encompasses students who are at the last grade of primary school in addition to the $9^{\text {th }}$ and $10^{\text {th }}$ grades. The target population of this study was comprised of high schools in Turkey and Singapore. The sample group of the study was comprised of 186 schools from Turkey and 174 schools from Singapore for a total of 360 schools.

\subsection{Data Acquisition Tools}

Analyses were carried out in this study by the $5^{\text {th }}, 6^{\text {th }}, 7^{\text {th }}$ and $8^{\text {th }}$ items of the variable SC017 in the PISA school questionnaire which is, "Is your school's capacity to provide instruction hindered by any of the following issues?". The data were acquired from the responses of school principals who participated in the PISA school questionnaire section from Turkey and Singapore. The school questionnaire is prepared to acquire information on the school characteristics, school resources, school employees, school organization, issue of environment in the program as well as the preparation of students for a more advanced education and professional guidance. The school questionnaire is filled out by the school principal within a time frame of 60 minutes.

\subsection{Data Analysis}

Descriptive analyses and chi-square statistics were used to put forth whether there are differences with regard to the items of "Lack of educational material", "inadequate or poor quality educational material", "lack of physical infrastructure", "inadequate or poor quality physical infrastructure" which are part of the variable SC017 entitled "Is your school's capacity to provide instruction hindered by any of the following issues?". Logistic regression analysis was used since the dependent variable determined within the scope of the study is double categorical (countries) and that the independent variables are continuous and/or sectional and since the objective of the study was to make an accurate classification of the schools according to their countries. The purpose of the logistic regression analysis is to estimate the value of the categorical dependent variable, hence the "membership" estimate for two or more groups actually being tried (Çokluk, Şekercioğlu, \& Büyüköztürk, 2010). Logistic regression has no assumption about the distribution of predictor variables. Despite this situation, multivariate normality and linearity among predictions may enhance power (Tabachnick \& Fidell, 1996).

\section{Results}

In this part of the study, the findings are presented on the basis of sub-problem. Results of the chi-square test carried out to examine whether there is a relationship between Singapore and Turkey with regard to lack of educational material have been given in Table 1 .

Table 1. Results of the chi-square test on the relationship between the countries with regard to lack of educational material

\begin{tabular}{|c|c|c|c|c|}
\hline \multirow{2}{*}{\multicolumn{2}{|c|}{ Lack of educational material }} & \multicolumn{2}{|c|}{ Countries } & \multirow{3}{*}{$\begin{array}{c}\text { Total } \\
194\end{array}$} \\
\hline & & \multirow{2}{*}{$\begin{array}{c}\text { Singapore } \\
150\end{array}$} & \multirow{2}{*}{$\frac{\text { Turkey }}{44}$} & \\
\hline \multirow{2}{*}{ None } & $\mathrm{N}$ & & & \\
\hline & $\%$ & 85.2 & 23.5 & 53.4 \\
\hline \multirow{2}{*}{ Very little } & $\mathrm{N}$ & 26 & 43 & 69 \\
\hline & $\%$ & 14.8 & 23 & 19 \\
\hline \multirow{2}{*}{ Some } & $\mathrm{N}$ & 0 & 67 & 67 \\
\hline & $\%$ & 0 & 35.8 & 18.5 \\
\hline \multirow{2}{*}{ A lot } & $\mathrm{N}$ & 0 & 33 & 33 \\
\hline & $\%$ & 0 & 17.6 & 9.1 \\
\hline \multirow{2}{*}{ Total } & $\mathrm{N}$ & 176 & 187 & 363 \\
\hline & $\%$ & 100 & 100 & 100 \\
\hline
\end{tabular}


When Table 1 is examined, it can be observed that $85.2 \%$ of the schools in Singapore have no lack of educational material according to the opinions of school administrators who participated in PISA 2015 from Singapore and that the remaining $14.8 \%$ has very little lack. Whereas there were no school administrators who are of the opinion that the lack of material is some or a lot in Singapore, $17.6 \%$ of the school administrators in Turkey indicated that the lack of educational material is a lot, and $35.8 \%$ reported it as some. The ratio of school administrators who are of the opinion that there is no lack of educational material in Turkey was $23.5 \%$; the ratio of those who are of the opinion that it is very little was $23 \%$. It can be put forth that the lack of educational material is a significant obstacle for the schools in Turkey to provide sufficient educational services. It is also observed that the difference between Singapore and Turkey with regard to lack of educational material is significant, $\chi^{2}(\mathrm{sd}=3, \mathrm{n}=363)=$ $161.92, \mathrm{p}<.05)$.

Results of the chi-square test carried out to examine whether there is a relationship between Singapore and Turkey with regard to inadequate or poor quality educational material have been given in Table 2 .

Table 2. Chi-Square test results on the relationship between the countries with regard to inadequate or poor quality educational material

\begin{tabular}{|c|c|c|c|c|}
\hline \multirow{2}{*}{\multicolumn{2}{|c|}{$\begin{array}{l}\text { Inadequate or poor quality educational } \\
\text { material }\end{array}$}} & \multicolumn{2}{|c|}{ Countries } & \multirow{3}{*}{$\begin{array}{c}\text { Total } \\
193\end{array}$} \\
\hline & & \multirow{2}{*}{$\begin{array}{c}\text { Singapore } \\
148\end{array}$} & \multirow{2}{*}{$\begin{array}{c}\text { Turkey } \\
45\end{array}$} & \\
\hline & $\mathrm{N}$ & & & \\
\hline None & $\%$ & 84.6 & 24.2 & 53.5 \\
\hline \multirow{2}{*}{ Very little } & $\mathrm{N}$ & 27 & 46 & 73 \\
\hline & $\%$ & 15.4 & 24.7 & 20.2 \\
\hline \multirow{2}{*}{ Some } & $\mathrm{N}$ & 0 & 62 & 62 \\
\hline & $\%$ & 0 & 33.3 & 17.2 \\
\hline \multirow{2}{*}{ A lot } & $\mathrm{N}$ & 0 & 33 & 33 \\
\hline & $\%$ & 0 & 17.7 & 9.1 \\
\hline \multirow{2}{*}{ Total } & $\mathrm{N}$ & 175 & 186 & 361 \\
\hline & $\%$ & 100 & 100 & 100 \\
\hline
\end{tabular}

$\chi^{2}=154.72, \mathrm{sd}=3, \mathrm{p}=.000$.

Table 2 also puts forth results that are similar to those in Table 1. Whereas $84.6 \%$ of the school administrators in Singapore are of the opinion that the educational material is neither inadequate nor poor quality, $15.4 \%$ indicate that it is very little. Of the school administrators in Turkey, $17.7 \%$ have put forth that the educational material is inadequate or poor quality, whereas the ratio of those who indicate it as some was $33.3 \%$. Whereas $24.7 \%$ of the school administrators in Turkey were of the opinion that lack of educational material or poor quality educational material is very little, those who do not consider educational material as inadequate or poor quality was $24.2 \%$. In comparison with Singapore, it can be stated that Turkey has greater problems with regard to inadequate or poor quality educational material. A statistically significant difference is observed between Singapore and Turkey, $\chi^{2}$ $(\mathrm{sd}=3, \mathrm{n}=361)=154.72, \mathrm{p}<.05$.

The level of the hindrance due to inadequate physical infrastructure was also examined for the schools from Singapore and Turkey which participated in PISA 2015. Results of the chi-square test carried out to determine whether the countries and lack of physical infrastructure are independent or not. 
Table 3. Chi-Square test results on the relationship between countries and lack of physical infrastructure

\begin{tabular}{|c|c|c|c|c|}
\hline \multirow{2}{*}{\multicolumn{2}{|c|}{ Lack of physical infrastructure }} & \multicolumn{2}{|c|}{ Countries } & \multirow{2}{*}{ Total } \\
\hline & & Singapore & Singapore & \\
\hline \multirow{2}{*}{ None } & $\mathrm{N}$ & 101 & 61 & 162 \\
\hline & $\%$ & 57.4 & 32.6 & 44.6 \\
\hline \multirow{2}{*}{ Very little } & $\mathrm{N}$ & 54 & 47 & 101 \\
\hline & $\%$ & 30.7 & 25.1 & 27.8 \\
\hline \multirow{2}{*}{ Some } & $\mathrm{N}$ & 20 & 53 & 73 \\
\hline & $\%$ & 11.4 & 28.3 & 20.1 \\
\hline \multirow{2}{*}{ A lot } & $\mathrm{N}$ & 1 & 26 & 27 \\
\hline & $\%$ & .6 & 13.9 & 7.4 \\
\hline \multirow{2}{*}{ Total } & $\mathrm{N}$ & 176 & 187 & 363 \\
\hline & $\%$ & 100 & 100 & 100 \\
\hline
\end{tabular}

$\chi^{2}=48.14, \mathrm{sd}=3, \mathrm{p}=.000$.

The ratio of school administrators who are of the opinion that there is no lack of physical infrastructure in Singapore was $57.4 \%$, whereas this ratio was $32.6 \%$ for Turkey. The ratio of school administrators who indicate the lack of physical infrastructure as very little in Singapore was 30.7\%, whereas this ratio was $25.1 \%$ for Turkey; the ratio of those who indicate the lack of physical infrastructure as some was $11.4 \%$ in Singapore and $28.3 \%$ in Turkey. Whereas only one of the school administrators was of the opinion that the lack of physical infrastructure is a lot in Singapore (.6\%), this ratio was $13.9 \%$ for Turkey. It is again observed that the lack of physical infrastructure between Turkey and Singapore is against Turkey even if it is not as drastic as that of the lack of educational material. A statistically significant difference is observed between Singapore and Turkey with regard to lack of physical infrastructure, $\chi^{2}(\mathrm{sd}=3, \mathrm{n}=363)=48.14, \mathrm{p}<.05$.

Results of the chi-square test carried out to determine whether there is a relationship between Singapore and Turkey with regard to inadequate or poor quality physical infrastructure or not have been given in Table 4 .

Table 4. Chi-Square test results on the relationship between countries and inadequate or poor quality physical infrastructure

\begin{tabular}{|c|c|c|c|c|}
\hline \multirow{2}{*}{\multicolumn{2}{|c|}{$\begin{array}{c}\text { Inadequate or poor quality physical } \\
\text { infrastructure }\end{array}$}} & \multicolumn{2}{|c|}{ Countries } & \multirow{2}{*}{ Total } \\
\hline & & \multirow{2}{*}{$\frac{\text { Singapore }}{102}$} & \multirow{2}{*}{$\frac{\text { Singapore }}{61}$} & \\
\hline & $\mathrm{N}$ & & & 163 \\
\hline None & $\%$ & 58.3 & 32.5 & 45 \\
\hline \multirow{2}{*}{ Very little } & $\mathrm{N}$ & 53 & 51 & 104 \\
\hline & $\%$ & 30.3 & 27.3 & 28.7 \\
\hline \multirow{2}{*}{ Some } & $\mathrm{N}$ & 18 & 50 & 68 \\
\hline & $\%$ & 10.3 & 26.7 & 18.8 \\
\hline \multirow{2}{*}{ A lot } & $\mathrm{N}$ & 2 & 25 & 27 \\
\hline & $\%$ & 1.1 & 13.4 & 7.5 \\
\hline \multirow{2}{*}{ Total } & $\mathrm{N}$ & 175 & 187 & 362 \\
\hline & $\%$ & 100 & 100 & 100 \\
\hline
\end{tabular}

$\chi^{2}=44.65, \mathrm{sd}=3, \mathrm{p}=.000$.

The results provided in Table 4 resemble those in Table 3.More than half of the school administrators in Singapore $(58.3 \%)$ have indicated that the physical infrastructure in their countries is not inadequate or poor quality. This ratio was $32.5 \%$ for Turkey. The ratio of school administrators who are of the opinion that the physical infrastructure in their countries is inadequate or poor quality was $30.3 \%$ in Singapore, whereas this ratio was $27.3 \%$ for Turkey. Whereas $10.3 \%$ of the school administrators in Singapore evaluate the lack of physical infrastructure or its lack of quality as "some" in Singapore, this ratio was $26.7 \%$ for Turkey. The ratio of school administrators who are of the opinion that the physical infrastructure in their countries is inadequate or poor quality was $1.1 \%$ for Singapore, whereas this ratio was $13.4 \%$ for Turkey. When the responses of school administrators regarding inadequate or poor quality physical infrastructure were examined, it can be observed that the administrators in Turkey have more negative opinions regarding the situation in their country. In addition, this 
difference was also determined to be statistically significant, $\chi^{2}(\mathrm{sd}=3, \mathrm{n}=362)=44.65, \mathrm{p}<.05$.

The objective of this study was to put forth a model that provides a more accurate classification of the schools according to countries with regard to variables related to the adequacy of educational resources. Enter method was used in the logistic regression carried out to develop a model. The first classification obtained as a result of the logistic regression analysis has been provided in Table 5 .

Table 5. First classification status

\begin{tabular}{lccc}
\hline \multirow{2}{*}{ Observed } & \multicolumn{2}{c}{ Predicted } & \multirow{2}{*}{ \% Correct } \\
\cline { 2 - 3 } & Singapore & Turkey & \\
\hline Singapore & 0 & 174 & 0 \\
Turkey & 0 & 186 & 100 \\
Overall \% correct & & 51.7 \\
\hline
\end{tabular}

The first classification estimation is calculated based on the assumption that all participants are members of the category that is higher in number in order to ensure that accurate classification by chance percentage is high. Accurate classification percentage was calculated as $51.7 \%$ when it was assumed that all schools participated from Turkey since the number of schools participating from Turkey was higher than that of Singapore. In other words, 360 schools can be classified accurately by chance at a ratio of $51.7 \%$ regardless of the effects of the predictor variables. Table6 shows a summary of the usefulness of the model.

Table 6. Summary of the usefulness of the model

\begin{tabular}{cccc}
\hline Step & $(-2 \mathrm{LL})$ & Cox \& Snell $\mathrm{R}^{2}$ & Nagelkerke $^{2}$ \\
\hline 1 & 286.079 & .446 & .595 \\
\hline
\end{tabular}

While -2LL is the likelihood value for the agreement of a model, Cox \& Snell $\mathrm{R}^{2}$ and Nagelkerke $\mathrm{R}^{2}$ values indicate the amount of variance explained by the model that is generated as a result of the logistic regression. Cox \& Snell $R^{2}$ value is difficult to interpret since its value never reaches the value of 1.00 ; therefore Nagelkerke $R^{2}$ value is used more often when interpreting (Çokluk et al., 2016). When Table 6 is examined, it can be observed that the $-2 \mathrm{LL}$ value is higher than expected. Predictor variables explain $59.5 \%$ of the total variance in the predicted variable according to the Nagelkerke $\mathrm{R}^{2}$ value. The value of 0.595 indicates that the model is useful in predicting countries. The classification obtained as a result of the logistic regression model has been given in Table 7 .

Table 7. Classification success of the model

\begin{tabular}{cccc}
\hline \multirow{2}{*}{ Observed } & \multicolumn{2}{c}{ Predicted } & \multirow{2}{*}{ \% Correct } \\
\cline { 2 - 3 } & Singapore & Turkey & \\
\hline Singapore & 152 & 22 & 87.4 \\
Turkey & 44 & 142 & 76.3 \\
Overall \% correct & & 81.7 \\
\hline
\end{tabular}

It can be seen from Table 7 that the success of classification in the logistic regression model for the variables related to the level of adequacy of educational material according to countries is $81.7 \%$. In other words, the model made an accurate estimation for the countries of $81.7 \%$ out of a total of 360 schools. This ratio is quite higher in comparison with accurate classification by chance $(51.7 \%)$ percentage. According to the acquired results, it can be observed that the model made an accurate classification for $152(87.4 \%)$ out of 174 Singapore schools and 142 (76.3\%) out of 186 Turkish schools.

The coefficients of the predictor variables in the model ( $(3)$, standard errors related to these coefficients, Wald statistics, levels of significance and $\operatorname{Exp}(ß)$ values have been given in Table 8. 
Table 8. Coefficient estimations for the model variables

\begin{tabular}{|c|c|c|c|c|c|c|}
\hline Predictor variables & $ß$ & $\begin{array}{c}\text { Standard } \\
\text { Error }\end{array}$ & Wald & sd & $\mathrm{p}$ & $\operatorname{Exp}(ß)$ \\
\hline Lack of educational material & 1.576 & .381 & 17.085 & 1 & .000 & 4.836 \\
\hline Inadequate or poor quality educational material & 1.556 & .425 & 13.401 & 1 & .000 & 4.742 \\
\hline Lack of physical infrastructure & -.161 & .349 & .212 & 1 & .645 & .852 \\
\hline Inadequate or poor quality physical infrastructure & -.597 & .367 & 2.649 & 1 & .104 & .550 \\
\hline Constant & -3.564 & .418 & 72.827 & 1 & .000 & .028 \\
\hline
\end{tabular}

It can be observed that the "Lack of educational material" and "Inadequate or poor quality educational material" variables have a statistically significant impact on the classification of schools as Singapore and Turkey. It is also observed that the variables of "Lack of physical infrastructure" and "Inadequate or poor quality physical infrastructure" do not have a statistically significant contribution to the model. The Odds ratios put forth that variables related to educational material have a greater impact in comparison with the variables related to physical infrastructure. It can be stated according to the acquired model that the difference between the Singapore and Turkey schools is due to the lack, inadequacy or poor quality of educational material rather than the lack, inadequacy or poor quality of physical infrastructure.

\section{Discussion, Conclusion and Suggestions}

In this study, it was examined whether there are differences between Singapore which was the most successful country in PISA 2015 and Turkey with regard to poor quality of educational material and inadequacy of physical infrastructure that are considered as obstacles in education. Statistically significant differences between Turkish and Singapore schools were obtained as a result of the chi-square analyses in all variables including lack of educational material, inadequate or poor quality educational material, lack of physical infrastructure and inadequate or poor quality physical infrastructure variables. Whereas $85 \%$ of the schools that participated from Singapore indicated that they do not experience lack of educational material, this ratio was $23 \%$ for Turkey. Similarly, whereas $85 \%$ of the Singapore schools indicated that they do not have inadequate or poor quality educational material problem, it is found that $76 \%$ of the schools in Turkey face the obstacle of inadequate or poor quality educational material at differing ratios. In other words, it is understood that majority of the Singapore schools do not experience a lack or inadequacy with regard to educational resources, whereas these issues are observed frequently in Turkey. Even though there is a statistically significant difference between the schools of the two countries with regard to lack of physical infrastructure as well, it was observed that this difference was lower in comparison with the lack of educational material. Whereas $41 \%$ of the schools in Turkey had the lack of physical infrastructure, this ratio was $12 \%$ in Singapore. It was observed that the acquired results are supported by the model developed by logistic regression. A total of four variables included in the study explain about $60 \%$ of the variance of Turkish and Singapore schools in having adequate educational resources. In addition, the equation obtained as a result of the logistic regression with these variables classifies $82 \%$ of the total number of 360 schools accurately. This ratio is much higher than the classification by chance (51.7\%) percentage.

A total of 72 countries, of which 35 were OECD members, have participated in PISA 2015. Singapore managed to become the first in all three literacy areas (science, reading and mathematics), whereas Turkey was below the OECD average in all three literacy areas. The fact that Singapore has been ranked high since 2009 when it first participated in PISA is an indication that its success is not coincidental. It is apparent that the quality of the educational material and the physical conditions of schools are among the significant concrete factors that affect education and learning. School administrators of some countries that participated in PISA 2003 have indicated that their inadequacies in physical infrastructure do not limit their education capacity significantly. However, school administrators in Turkey, Norway and Greece have complained about the physical infrastructure problems and this issue reflects the quality of education. It is thought that there is no relation between physical resources and student performance in only a few countries. School administrators in Mexico, Greece, Poland, Turkey, Lithuania, Brazil, Thailand, Serbia, Indonesia, Tunisia, Uruguay, Russia have indicated that they are of the opinion that not having educational material at schools or having poor quality educational material is directly related with the quality of education ("Learning for Tomorrow's World: First Results from PISA 2003", 2004).

In a study done by Demir, Ünal, and Kılıç (2010) to examine the impact of the quality of educational resources on the success of students in mathematics based on PISA 2006 Turkey data, they concluded that both technological and non-technological educational resources are important in the mathematics success of students. Exline (1989) mentions that teachers, parents and students consider course books as an important element of science education 
and indicates the necessity of developing course books into more effective tools by establishing open communication between publishers and users. In her study based on PISA 2012 data, Özer-Özkan (2016) who examines the variables that are effective in classifying schools according to their successes determined that the quality of educational resources had a statistically significant impact on the model and reached the conclusion that an increase of 1 unit in this variable led to an increase of about 2 times in school success. Oliveira (1995) mentions three criteria that affect the quality of course books. These are; encompassing the curriculum, usability and motivation. Publishers should provide a scope and classification matrix emphasizing how the official curriculum of the state overlaps with the book thereby enabling the teachers to have access to the scope. Practicality or ease of use is important for teachers. This is an indication that teachers will tend to choose course books and materials that are best suited for easy use in daily classes. Another critical factor that teachers take into consideration is student participation. Ease of use affects student behavior in classes and difficult books may tend to decrease the motivation of students towards the course. Based on their experiences, teachers tend to select books which are easy to understand for the students. Research shows that although textbooks and student materials play an important role in increasing student achievement, they alone are not enough. If the teachers have not received proper training on how to use this material or if they are not willing to use such material, quality education material may not be as effective as considered to increase success (Karip \& Köksal, 1996). Verspoor (1989) emphasizes the necessity that all factors in an education program such as teachers, course books, curriculum and teaching methods should be at the same developmental level. He states that expecting unskilled teachers to use course books designed for more experienced teachers is a recipe for failure.

According to Aküzel (2006), in addition to course book and teacher pair, there are different resources providing significant impact during the teaching process. In general, these resources are visual and auditory tools. It is put forth that the motivation and level of understanding of students increase in direct proportion with how much such tools are used in class. Since materials such as projection devices, computers, and smart boards appeal to the students' sense of sight and hearing, these materials increase students' interest to the lesson and provide more effective learning. Dursun and Dede (2004) carried out a study in which they put forth that lack of material in schools has adverse effects on student success. In this study, it was determined that having sufficient educational material has a positive impact on student success. Çelik and Katılmış (2010) carried out a study in which a social studies course equipped with different visual and auditory material increased the success of the students in social studies at a statistically significant level.

PISA evaluation studies help in understanding the current results of education systems and may act as a mediator in increasing the quality of future educational policies by way of comparisons between countries (Aydin, Erdağ, \& Taş, 2011).The common points among countries that were successful in PISA 2015 were: high and universal expectations for all students, a strong focus on great teaching, resources targeted at struggling students and schools, and a commitment to coherent, long-term strategies (Singapore Tops Latest OECD Pisa Global Education Survey, 2016). Gür, Çelik, and Özoğlu (2012) have attracted attention to the fact that PISA results may be used erroneously in policy determination and that it would be wrong to change the curriculum in Turkey based solely on the PISA results without first taking the developmental steps in line with the analyses of the real issues of the Turkish education system in an accurate manner. Deng and Gopinathan (2016) carried out a study in which they tried to explain the success of Singapore in PISA in which they argue that the secret formula behind the success of Singapore is based on teacher quality, school leadership, characteristics of the education system and educational reforms. Therefore, it is not possible to expect that improving educational resources will bring forth success by itself. However, even though there are many variables that affect success in education, it is considered that closing the gap between Singapore and Turkey with regard to the material elements related to educational material will contribute to increasing the success of Turkey.

The use of public resources may be allocated to improving physical infrastructure with the impact of demographic conditions. In addition to being a meaningful policy to give fast responses to the requirements, it is important to set as a philosophy that the quality of educational resources is more important than the physical resources. Therefore, it can be stated that overcoming the inadequacies in educational material in Turkey which have direct impacts on teaching should be considered to have more priority than eliminating physical inadequacies. As a general conclusion of the study, it was observed with regard to its contributions to the model acquired via logistic regression analysis that lack of educational material is more important than lack of physical infrastructure. This alone puts forth that school success is related more to the quality of educational material than to physical inadequacies.

\section{References}

Akpınar, B., \& Aydın, K. (2007). A comparison of educational reforms in Turkey and other countries. Research 
of Eastern Anatolia Region, 6(1), 82-88.

Aküzel, G. (2006). İlköğretim 4-8. sinfflarda yabancı dil öğretimindeki başarısızlık nedenlerinin incelenmesi, Yüksek Lisans Tezi, Çukurova Üniversitesi Sosyal Bilimler Enstitüsü, Adana (pp. 15-16).

Anıl, D. (2010).Factors effecting science achievement of science students in Programme for International Students' Achievement (PISA) in Turkey. Education and Science, 34(152), 87-100.

Aydın, A., Erdağ, C., \& Taş, N. (2011). A Comparative Evaluation of Pisa 2003-2006 Results in Reading Literacy Skills: An Example of Top-Five OECD Countries and Turkey. Educational Sciences: Theory and Practice, 11(2), 665-673.

Bakan, İ., \& Büyükbeşe, T. (2004). Çalışanların iş güvencesi ve genel iş davranışları ilişkisi: Bir alan çalışması. Erciyes Üniversitesi İktisadi ve İdari Bilimler Fakültesi Dergisi, 23, 35-59.

Bakioğlu, A., \& Göçmen, G. (2013). Singapur eğitim sistemi. In A. Bakioğlu (Ed.), Karşılaş̧tırmalı eğitim yönetimi (pp. 127-155). Ankara: Nobel Akademik Yayıncıllk.

Çelik, H., \& Katılmış, A. (2010). Sosyal Bilgiler Öğretmenlerinin Derslerindeki Öğrenci Başarısını Etkileyen Unsurlara İlişkin Görüşleri, Marmara Coğrafya Dergisi, 22(7), 128-153.

Çelik, L. (2007). Öğretim materyallerinin hazırlanması ve seçimi. In Ö. Demirel (Ed.), Öğretim teknolojileri ve materyal tasarımı. Ankara: Pegem A Yayincilık.

Cemaloğlu, N. (2016). Singapur Eğitim Sistemi. Retrieved from http://www.kamudanhaber.net/singapur-egitim-sistemi-makale,3304.html

Çokluk, Ö., Şekercioğlu, G., \& Büyüköztürk, Ş. (2016). Sosyal bilimler için çok değişkenli istatistik: SPSS ve LISREL uygulamaları. Pegem Akademi.

Davis, N. (2003). Technology in teacher education in the USA: What makes for sustainable good practice? Technology, Pedagogy and Education, 12(1), 59-84. https://doi.org/10.1080/14759390300200146

Demir, İ., Ünal, H., \& Kılıç, S. (2010). The effect of quality of educational resources on mathematics achievement: Turkish case from PISA-2006. Procedia-Social and Behavioral Sciences, 2(2), 1855-1859. https://doi.org/10.1016/j.sbspro.2010.03.998

Deng, Z., \& Gopinathan, S. (2016). PISA and high-performing education systems: Explaining Singapore's $\begin{array}{llll}\text { education } & \text { success. } & \text { Comparative } & \text { Education, }\end{array}$ https://doi.org/10.1080/03050068.2016.1219535

Dursun, Ş., \& Dede, Y. (2004). The factors affecting students' success in mathematics: Mathematics teachers' perspectives. Gazi University, The Journal of the Education Faculty, 24(2), 217-230.

Education at a GlanceSingapore. (2016). Retrieved from https://data.gov.sg/group/education

Education in Singapore. (n.d.). Singapur Ĕ̈itim Bakanlığg. Retrieved from https://www.moe.gov.sg

Eğitim Reformu Girişimi (ERG). (2005). Eğitimi İzleme raporu 2005-2006.

Eğitim Reformu Girişimi (ERG). (2016). Eğitimi İzleme raporu 2015-2016.

Ergün, M. (1985). Karşılaştırmalı Eğitim. Retrieved from http://www.egitim.aku.edu.tr/kegitim.pdf

Exline, J. D. (1989). Better textbook activities for better science education: A special section on the improvement of textbooks. Science Activities: Classroom Projects and Curriculum Ideas, 26(2), 19. https://doi.org/10.1080/00368121.1989.9956673

Gedikoğlu, T. (2005). Avrupa Birliği sürecinde Türk eğitim sistemi: Sorunlar ve çözüm önerileri. Mersin Üniversitesi Ĕgitim Fakültesi Dergisi, 1(1), 66-80.

Güngör, G., \& Göksu, A. (2013). Education finance in Turkey and an intercountry comparison. Journal of Management and Economics: The Faculty of Economic and Administrative Sciences Journal, 20(1), 59-72.

Gür, B. S., Çelik, Z., \& Özoğlu, M. (2012). Policy options for Turkey: A critique of the interpretation and utilization of PISA results in Turkey. Journal of Education Policy, 27(1), 1-21. https://doi.org/10.1080/02680939.2011.595509

Karasar, N. (2008). Bilimsel araştırma yöntemi, ilkeler, teknikler. İstanbul: Nobel Yayınları.

Karip, E., \& Köksal, K. (1996). Etkili eğitim sistemlerinin geliştirilmesi. Kuram ve Uygulamada Eğitim Yönetimi Dergisi, 2(2), 245-257. 
Learning for Tomorrow's World: First Results from PISA 2003. (2004). OECD Publications Centre.

MEB [Ministry of National Education Republic of Turkey]. (2016). TIMSS 2015Tanıtım Kitap̧̧ı̆̆ [TIMSS 2015 Prospectuses]. Retrieved from http://timss.meb.gov.tr/wp-content/uploads/Tanitim_Kitapcigi.pdf

MEB Strateji Geliştirme Başkanlığı. (2015). Retrieved from http://www.meb.gov.tr

Ministry of EducationSingapore. (2016). Retrieved from http://www.moe.edu.sg

Mullis, I. V., Martin, M. O., Foy, P., \& Arora, A. (2012). TIMSS 2011 international results in mathematics. International Association for the Evaluation of Educational Achievement. Herengracht 487, Amsterdam, 1017 BT, The Netherlands.

OECD. (2016). Education at a Glance 2016: OECD Indicators. OECD Publishing, Paris. Retrieved from http://download.ei-ie.org/Docs/WebDepot/EaG2016_EN.pdf

Oliveira, J. B. (1995). Understanding textbook quality in the USA: How governments distort the market. International review of education, 41(6), 481-500. https://doi.org/10.1007/BF01263142

Özer-Özkan, Y. (2016). Examining the effective variables on classification of school's success through PISA 2012 Turkey data. International Online Journal of Educational Sciences, 8(2), 117-130. https://doi.org/10.15345/iojes.2016.02.011

PISA 2015 Results in Focus. (2016). Retrieved from http://www.oecd.org/pisa/pisa-2015-results-in-focus.pdf

Şahin, Y. T., \& Yıldırım, S. (1999). Öğretim teknolojileri ve materyal gelişstirme. Ankara:Anı Yayıncılık.

Sarışı1k, Y., \& Düşkün, Y. (2016). Çocukların gözünden okulda yaşam. İstanbul: ERG ve TEGV.

Singapore in Figures. (2016). Retrieved from https://www.singstat.gov.sg/docs/default-source/defaultdocument-library/publications/publications_and_papers/reference/sif2016.pdf

Singapore Tops Latest OECD Pisa Global Education Survey. (2016). Education Journal, 289, 7-9.

Tabachnick, B. G., \& Fidell, L. S. (2001). Using multivariate statistics. Boston: Ally and Bacon Pearson Education, Inc.

Verspoor, A. (1989). Using textbooks to improve the quality of education. Textbooks in the developing world: Economic and educational choices (pp. 52-58).

Walford, V. (2003). Defining and evaluating SWAps. London: Institute for Health Sector Development.

World Bank. (2016). Retrieved from http://data.worldbank.org/indicator/

\section{Copyrights}

Copyright for this article is retained by the author(s), with first publication rights granted to the journal.

This is an open-access article distributed under the terms and conditions of the Creative Commons Attribution license (http://creativecommons.org/licenses/by/4.0/). 